\title{
TRANC - a novel fast-response converter to measure total reactive atmospheric nitrogen
}

\author{
O. Marx ${ }^{1}$, C. Brümmer ${ }^{2}$, C. Ammann ${ }^{3}$, V. Wolff ${ }^{3}$, and A. Freibauer ${ }^{2}$ \\ ${ }^{1}$ LI-COR Biosciences GmbH, Bad Homburg vor der Höhe, Germany \\ ${ }^{2}$ Johann Heinrich von Thünen-Institute, Braunschweig, Germany \\ ${ }^{3}$ Swiss Federal Research Station Agroscope ART, Zürich, Switzerland
}

Correspondence to: C. Brümmer (christian.bruemmer@vti.bund.de and TRANC@oliver-marx.de)

Received: 9 November 2011 - Published in Atmos. Meas. Tech. Discuss.: 19 December 2011

Revised: 15 March 2012 - Accepted: 25 April 2012 - Published: 11 May 2012

\begin{abstract}
The input and loss of plant available nitrogen (reactive nitrogen: $\mathrm{N}_{\mathrm{r}}$ ) from/to the atmosphere can be an important factor for the productivity of ecosystems and thus for its carbon and greenhouse gas exchange. We present a novel converter for reactive nitrogen (TRANC: Total Reactive Atmospheric Nitrogen Converter), which offers the opportunity to quantify the sum of all airborne reactive nitrogen compounds $\left(\sum \mathrm{N}_{\mathrm{r}}\right)$ in high time resolution. The basic concept of the TRANC is the full conversion of all $\mathrm{N}_{\mathrm{r}}$ to nitrogen monoxide (NO) within two reaction steps. Initially, reduced $\mathrm{N}_{\mathrm{r}}$ compounds are being oxidised, and oxidised $\mathrm{N}_{\mathrm{r}}$ compounds are thermally converted to lower oxidation states. Particulate $\mathrm{N}_{\mathrm{r}}$ is being sublimated and oxidised or reduced afterwards. In a second step, remaining higher nitrogen oxides or those generated in the first step are catalytically converted to NO with carbon monoxide used as reduction gas. The converter is combined with a fast response chemiluminescence detector (CLD) for NO analysis and its performance was tested for the most relevant gaseous and particulate $\mathrm{N}_{\mathrm{r}}$ species under both laboratory and field conditions. Recovery rates during laboratory tests for $\mathrm{NH}_{3}$ and $\mathrm{NO}_{2}$ were found to be 95 and $99 \%$, respectively, and $97 \%$ when the two gases were combined. In-field longterm stability over an 11-month period was approved by a value of $91 \%$ for $\mathrm{NO}_{2}$. Effective conversion was also found for ammonium and nitrate containing particles. The recovery rate of total ambient $\mathrm{N}_{\mathrm{r}}$ was tested against the sum of individual measurements of $\mathrm{NH}_{3}, \mathrm{HNO}_{3}, \mathrm{HONO}, \mathrm{NH}_{4}^{+}, \mathrm{NO}_{3}^{-}$, and $\mathrm{NO}_{\mathrm{x}}$ using a combination of different well-established devices. The results show that the TRANC-CLD system precisely captures fluctuations in $\sum \mathrm{N}_{\mathrm{r}}$ concentrations and also
\end{abstract}

matches the sum of all individual $\mathrm{N}_{\mathrm{r}}$ compounds measured by the different single techniques. The TRANC features a specific design with very short distance between the sample air inlet and the place where the thermal and catalytic conversions to NO occur. This assures a short residence time of the sample air inside the instrument, and minimises wall sorption problems of water soluble compounds. The fast response time (e-folding times of 0.30 to $0.35 \mathrm{~s}$ were found during concentration step changes) and high accuracy in capturing the dominant $\mathrm{N}_{\mathrm{r}}$ species enables the converter to be used in an eddy covariance setup. Although a source attribution of specific $\mathrm{N}_{\mathrm{r}}$ compounds is not possible, the TRANC is a new reliable tool for permanent measurements of the net $\sum \mathrm{N}_{\mathrm{r}}$ flux between ecosystem and atmosphere at a relatively low maintenance and reasonable cost level allowing for diurnal, seasonal and annual investigations.

\section{Introduction}

\subsection{Reactive nitrogen}

Nitrogen is an essential nutrient for all living organisms. Beside dinitrogen $\left(\mathrm{N}_{2}\right)$, being practically inert and constituting $78 \%$ of the earth's atmosphere (Seinfeld and Pandis, 2006), the important nitrogen-containing trace species are nitric oxide (NO, also nitrogen monoxide), nitrogen dioxide $\left(\mathrm{NO}_{2}\right)$, nitric acid $\left(\mathrm{HNO}_{3}\right)$, ammonia $\left(\mathrm{NH}_{3}\right)$, and nitrous oxide $\left(\mathrm{N}_{2} \mathrm{O}\right)$ (Sutton et al., 2011). The sum of $\mathrm{NO}$ and $\mathrm{NO}_{2}$, the former emitted by both natural and anthropogenic sources, the latter formed in the atmosphere by oxidation of $\mathrm{NO}$ and 
emitted in small quantities from combustion processes along with $\mathrm{NO}$, is usually designated as $\mathrm{NO}_{\mathrm{x}}$. Reactive odd nitrogen, denoted $\mathrm{NO}_{\mathrm{y}}$, is defined as the sum of $\mathrm{NO}_{\mathrm{x}}$ and all products of the atmospheric oxidation of $\mathrm{NO}_{\mathrm{x}}$. These include among others $\mathrm{HNO}_{3}$, nitrous acid (HONO), and peroxyacetyl nitrate (PAN). $\mathrm{HNO}_{3}$ is rapidly deposited on surfaces and in water droplets and - in the presence of $\mathrm{NH}_{3}-$ can form ammonium nitrate $\left(\mathrm{NH}_{4} \mathrm{NO}_{3}\right)$ aerosols. Significant sources of $\mathrm{NH}_{3}$ are animal waste, ammonification of humus followed by emission from soils, losses of $\mathrm{NH}_{3}$-based fertilizers, and industrial emissions. In this paper, we define reactive nitrogen $\left(\mathrm{N}_{\mathrm{r}}\right)$ as all nitrogen-containing trace species except for $\mathrm{N}_{2}$ and $\mathrm{N}_{2} \mathrm{O}$ with the latter being inert in the troposphere (Seinfeld and Pandis, 2006). The oxidation states of the main $\mathrm{N}_{\mathrm{r}}$ compounds range from +5 for $\mathrm{HNO}_{3}$ to -3 for $\mathrm{NH}_{3}$.

The input of $\mathrm{N}_{\mathrm{r}}$ into an ecosystem through atmospheric dry deposition is an important factor for its productivity and thus for its exchange of carbon dioxide $\left(\mathrm{CO}_{2}\right)$ and other greenhouse gases. The dry deposition of $\mathrm{N}_{\mathrm{r}}$ typically contributes between one third and two thirds to the total atmospheric $\mathrm{N}$ deposition (Simpson et al., 2006). The environmental effects of excess atmospheric $\mathrm{N}_{\mathrm{r}}$ deposition to ecosystems may include soil acidification, eutrophication of water bodies, nutrient imbalances, leaching of base cation and nitrate, loss of biodiversity, direct toxicity to plants, increased $\mathrm{N}_{2} \mathrm{O}$ emissions, and inhibition of soil methane $\left(\mathrm{CH}_{4}\right)$ oxidation ( $\mathrm{Gal}-$ loway et al., 2003; Erisman et al., 2007; Flechard et al., 2011).

\subsection{Exchange measurements of reactive nitrogen compounds}

Unlike wet deposition, which is widely monitored in regional networks of wet-only or bulk precipitation collectors, measurements of overall dry (turbulent) $\mathrm{N}_{\mathrm{r}}$ exchange fluxes have largely remained experimental and were limited to selected research sites and to measurement campaigns of typically a few days to a few months due to technical complexity and to the large equipment and operational costs involved (Flechard et al., 2011) except for multi-year $\mathrm{NO}_{\mathrm{y}}$ eddy flux measurements at Harvard forest presented in Munger et al. (1996, 1998) and in Horii et al. (2006). This is due to the fact that dry $\mathrm{N}_{\mathrm{r}}$ exchange constitutes a variety of compounds with different exchange patterns and that in general, concentration and flux measurements of $\mathrm{N}_{\mathrm{r}}$ species are challenging from a metrological point of view (e.g. von Bobrutzki et al., 2010; Wolff et al., 2010a). Well-established measurement techniques (e.g. using chemiluminescence detectors CLD, molybdenum converter, denuder/impinger/filter sampling with ion chromatography analysis) are usually limited to single compounds (e.g. Sutton et al., 2007) or provide concentration values and flux rates in poor time resolution and require labour and cost-intensive lab analyses (Dämmgen and Zimmerling, 2002; Zimmerling et al., 1997).
Additionally, reliable, robust, interference-free, fast and precise detectors suitable for long-term micrometeorological flux measurements are available only for few $\mathrm{N}_{\mathrm{r}}$ compounds. They are, however, essential for permanent monitoring of the $\mathrm{N}_{\mathrm{r}}$ exchange between ecosystems and the atmosphere within an eddy-covariance (EC) setup. EC is the currently preferred method to measure continuously the exchange of $\mathrm{CO}_{2}$, water vapour and sensible heat over time scales of hours to decades, thus enabling the evaluation of seasonal and interannual variability in these exchanges and the elucidation of their climatic controls (Baldocchi et al., 2001; Coursolle et al., 2006; Brümmer et al., 2012a). In the last decade, substantial progress has been made in the use of tunable diode laser absorption spectroscopy (TDLAS) and quantum cascade lasers (QCL) as well as devices originating from individual applications such as Fourier transform infrared (FTIR) spectrometers. The precision and fast response of these approaches has allowed first EC measurements of field scale $\mathrm{N}_{2} \mathrm{O}$ and $\mathrm{CH}_{4}$ fluxes (Rinne et al., 2005; Denmead et al., 2010; Kroon et al., 2010; Neftel et al., 2010; Tuzson et al., 2010) as well as first $\mathrm{NO}_{2}$ fluxes (Horii et al., 2004), whereas measurements of $\mathrm{NH}_{3}$ fluxes by $\mathrm{EC}$ have been extremely limited (Famulari et al., 2004; Sutton et al., 2007; Sintermann et al., 2011), and are subject to substantial uncertainty (e.g. Shaw et al., 1998). Further problems in measuring $\mathrm{N}_{\mathrm{r}}$ compounds are the lack of capable techniques for fastresponse detection, issues regarding inlet design, sampling losses and air column chemical reactions for highly reactive and soluble $\mathrm{N}_{\mathrm{r}}$ species (Horii et al., 2004, 2006). Hence, the establishment of large-scale dry deposition monitoring networks of total $\mathrm{N}_{\mathrm{r}}$ remains nearly impracticable.

Chemiluminescence detectors (CLD) allow fast and reliable measurements of $\mathrm{NO}$ and - in combination with commercially available converters - of $\mathrm{NO}_{2}, \mathrm{NO}_{\mathrm{x}}$ and $\mathrm{NO}_{\mathrm{y}}$, respectively. These instruments are either using a graphite, a molybdenum oxide $(\mathrm{MoO})$ or a gold $(\mathrm{Au})$ converter operating at temperatures between 275 and $390^{\circ} \mathrm{C}$, whereas $\mathrm{Au}$ converters need a reducing agent like $\mathrm{CO}$ or $\mathrm{H}_{2}$. Early work by Sigsby et al. (1973) and Winer et al. (1974) describe a chemiluminescent method for analysis of nitrogen containing compounds in mobile source emissions $\left(\mathrm{NO}, \mathrm{NO}_{2}\right.$, $\mathrm{NH}_{3}$ ) and the response of chemiluminescent $\mathrm{NO}-\mathrm{NO}_{2}$ analyzers to other nitrogen-containing compounds while stressing the importance of correcting for interferences, e.g. under high PAN levels, respectively. Using fast-response NO detection by CLD, some approaches of long-term $\mathrm{NO}_{\mathrm{y}}$ measurements using EC have been conducted. For example, Munger et al. (1996), report on five years of $\mathrm{NO}_{\mathrm{y}}$ eddy flux data measured at Harvard forest, where $\mathrm{NO}_{\mathrm{y}}$ was determined following reduction to $\mathrm{NO}$ by $\mathrm{H}_{2}$ on a Au catalyst.

EC-based measurements of $\mathrm{N}_{\mathrm{r}}$ compounds other than $\mathrm{NO}_{\mathrm{x}}$ are extremely limited. Day et al. (2002) and Farmer et al. (2006) present the application of a thermal dissociation laser-induced fluorescence (TD-LIF) instrument suitable for the measurement of $\mathrm{NO}_{2}, \mathrm{HNO}_{3}$, alkyl ( $\left.\sum \mathrm{AN}\right)$ and peroxy 
nitrates ( $\left.\sum \mathrm{PN}\right)$. In this approach, each class of compounds thermally dissociates to $\mathrm{NO}_{2}$ and an accompanying radical $\left(\mathrm{RO}_{2}, \mathrm{RO}, \mathrm{OH}\right)$ in separately thermostatted ovens at temperatures of 180,330 , and $550^{\circ} \mathrm{C}$ for $\sum \mathrm{PN}, \sum \mathrm{AN}$, and $\mathrm{HNO}_{3}$, respectively. Sintermann et al. (2011) use a system for fast $\mathrm{NH}_{3}$ measurements with chemical ionisation mass spectrometry (CIMS) based on a commercial Proton Transfer Reaction-Mass Spectrometer (PTR-MS) within an EC setup over two agricultural fields in Oensingen, Switzerland, whereas the EC fluxes of $\mathrm{NH}_{3}$ measured by Famulari et al. (2004) during a two-month field campaign were conducted by the use of a TDLAS system.

In the absence of fast-response instruments suitable for EC measurements, the aerodynamic gradient method is frequently applied for $\mathrm{N}_{\mathrm{r}}$ compounds such as $\mathrm{NH}_{3}, \mathrm{HNO}_{3}$, HONO, and aerosol particles. It infers the flux from concentration measurements at several heights and measured turbulence characteristics. Concentration measurements are frequently performed by denuder or filter-pack sampling in combination with on- or offline analysis by ionchromatography and/or flow injection analysis, e.g. for $\mathrm{NH}_{3}$ in the AMANDA system (Wyers et al., 1993), or for $\mathrm{HNO}_{3}$ and aerosol particles in the GRAEGOR system (Thomas et al., 2009; Twigg et al., 2011). However, this method has proved to be relatively labour and cost intensive, often shows limited time resolution and brings along method-linked limitations. Only very few long term measurements are published (Flechard and Fowler, 1998; Flechard et al., 2010).

Measurements of total $\mathrm{N}_{\mathrm{r}}$ have been reported by McCalley and Sparks (2009) using selective thermal and chemical decomposition converters to reduce or oxidise all $\mathrm{N}_{\mathrm{r}}$ trace gases to NO. However, their setup was applied for relatively slow enclosure measurements over short experimental periods to determine the soil-atmosphere exchange of $\mathrm{NO}, \mathrm{NO}_{\mathrm{y}}$, and $\mathrm{NH}_{3}$ differentially by switching between different converter configurations. No information is given on the influence of the enclosures and sampling tubes in the field configuration on the performance of the system.

Although the knowledge of total $\mathrm{N}_{\mathrm{r}}$ exchange is of major importance for the compilation of matter flux balances on ecosystem level, none of the above-mentioned methods is capable of determining total $\mathrm{N}_{\mathrm{r}}$ in high time resolution within longterm monitoring setups. The reasons for this limitation are (a) the wide range of $\mathrm{N}_{\mathrm{r}}$ containing compounds, their different molecular and exchange characteristics and thus different sampling and measuring approaches, (b) the interactions between different $\mathrm{N}_{\mathrm{r}}$ compounds due to gas phase reactions (e.g. Meixner, 1994) and gas-aerosol particle interactions (e.g. Wolff et al., 2010b), and therefore the necessity to measure several parameters simultaneously, and (c) the complexity and labour-intensity of flux measurements of the individual compounds.

\subsection{Motivation and objectives of present study}

In this study, we present a novel converter named TRANC (Total Reactive Atmospheric Nitrogen Converter), which, in combination with a fast-response analyser (CLD), offers the opportunity to quantify the sum of all airborne $\mathrm{N}_{\mathrm{r}}$ compounds (denoted here as $\sum \mathrm{N}_{\mathrm{r}}$ ) in high time resolution. The design of the TRANC is supposed to fulfil the requirements needed for an operation within an EC setup. These requirements are an instantaneous oxidation and reduction of all $\mathrm{N}_{\mathrm{r}}$ compounds in the sample air to $\mathrm{NO}$ with the conversion occurring close to the air inlet, thereby reducing errors due to chemical reactions, particularly of $\mathrm{NH}_{3}$, in the sampling tube. To our knowledge, this is the first approach that is on the one hand not limited to a single or a few $\mathrm{N}_{\mathrm{r}}$ compounds, but provides the quantification of the sum of all $\mathrm{N}_{\mathrm{r}}$ compounds, and that is on the other hand fast enough to be used for EC measurements if combined with a fast-response NO analyser, thus presenting a new methodology for permanent exchange measurements of $\sum \mathrm{N}_{\mathrm{r}}$ at a relatively low maintenance level. The purpose of this paper is the presentation of the converter, its characteristics and results of performance tests. Validation and long-term application of the converter for EC flux measurements is presented in companion papers by Ammann et al. (2012) and Brümmer et al. (2012b).

\section{Experimental setup}

\subsection{Converter principle and design}

The basic concept of the TRANC is the full conversion of all $\mathrm{N}_{\mathrm{r}}$ compounds in the sample air to $\mathrm{NO}$ in two reaction steps. Initially, reduced $\mathrm{N}_{\mathrm{r}}$ compounds are being oxidised, whereas oxidised $\mathrm{N}_{\mathrm{r}}$ compounds are thermally converted to compounds of lower oxidation states. Particulate $\mathrm{N}_{\mathrm{r}}$ is being sublimated and oxidised or reduced afterwards. The conversions in the first reaction step, i.e. the thermal conversions, occur at temperatures $\geq 870^{\circ} \mathrm{C}$. In a second step, i.e. the catalytic conversion, remaining higher nitrogen oxides in the sample air or those originated in the first reaction step are converted on a Au surface $\left(\geq 300^{\circ} \mathrm{C}\right)$ to $\mathrm{NO}$ with carbon monoxide (CO) used as reduction gas and by installing a platinum (Pt) gauze ensuring a complete catalytic conversion of $\mathrm{NH}_{3}$ to $\mathrm{NO}$. The main conversions resulting under these conditions are as follows:

$$
\begin{aligned}
& \mathrm{NH}_{4} \mathrm{NO}_{3} \stackrel{\Delta T}{\longrightarrow} \mathrm{NH}_{3} \uparrow+\mathrm{HNO}_{3} \uparrow \\
& 2 \mathrm{HNO}_{3} \stackrel{\Delta T}{\longrightarrow} 2 \mathrm{NO}_{2}+\mathrm{H}_{2} \mathrm{O}+1 / 2 \mathrm{O}_{2} \\
& \mathrm{HONO} \stackrel{\Delta T}{\longrightarrow} \mathrm{NO}+\mathrm{OH} \\
& 4 \mathrm{NH}_{3}+5 \mathrm{O}_{2} \stackrel{\Delta T, \mathrm{Pt}}{\longrightarrow} 4 \mathrm{NO}+6 \mathrm{H}_{2} \mathrm{O} \\
& \mathrm{NO}_{2}+\mathrm{CO} \stackrel{\Delta T, \mathrm{cat}}{\longrightarrow} \mathrm{NO}+\mathrm{CO}_{2}
\end{aligned}
$$




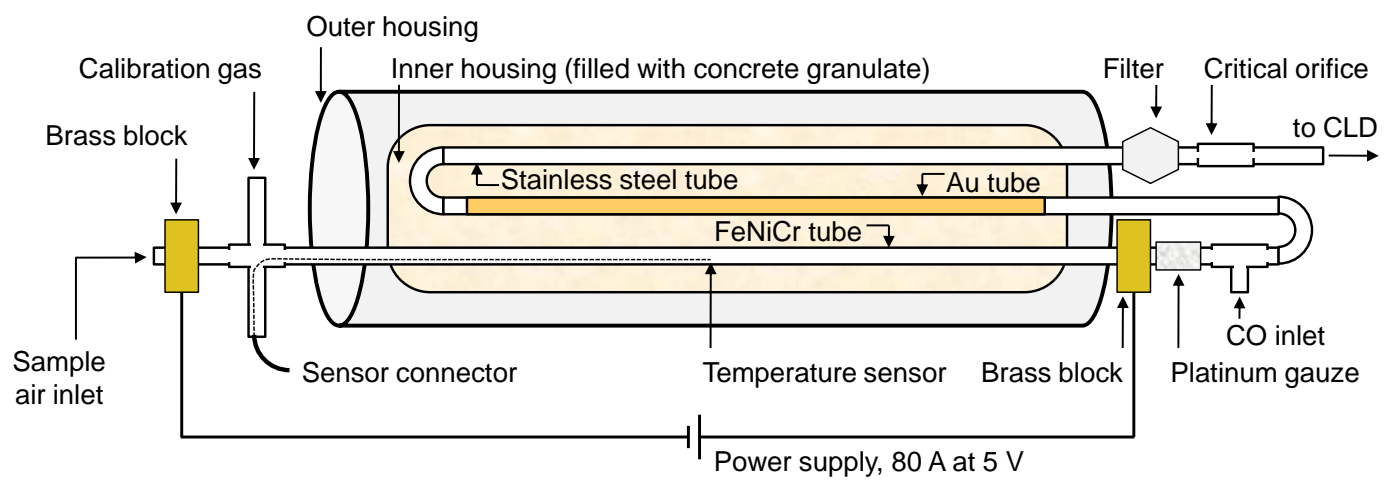

Fig. 1. Design of the total reactive atmospheric nitrogen converter (TRANC) (not true to scales).

Finally, the NO concentration in the gas sample leaving the converter towards a CLD represents the initial $\sum \mathrm{N}_{\mathrm{r}}$ concentration that entered the converter through the sample air inlet. Regarding decomposition temperatures of the most abundant $\mathrm{N}_{\mathrm{r}}$ compounds being significantly lower than 870 and $300^{\circ} \mathrm{C}$ during the thermal and catalytic reaction steps, respectively, we assume a full conversion of all $\mathrm{N}_{\mathrm{r}}$ in the sample air to NO. The conversion efficiency of single $\mathrm{N}_{\mathrm{r}}$ compounds was tested in several laboratory and field experiments and is described in Sects. 3.1 and 3.2.

A schematic overview of the TRANC is presented in Fig. 1. Core piece of the converter is a high-temperature resistant metal tube (length $l=780 \mathrm{~mm}$, outer diameter $\mathrm{OD}=6.35 \mathrm{~mm}$, inner diameter $\mathrm{ID}=4.57 \mathrm{~mm}$ ) consisting of an iron-nickel-chrome (FeNiCr) alloy. The tube is encapsulated in a double-walled, weather-sealed aluminium housing $(l=705 \mathrm{~mm}, \mathrm{OD}=120 \mathrm{~mm}$ of outer box $)$. The inner box $(l=650 \mathrm{~mm}, \mathrm{OD}=90 \mathrm{~mm})$ is filled with high-temperature resistant concrete granulate assuring effective heat insulation. Outside the outer housing, the $\mathrm{FeNiCr}$ tube is connected to a Pt gauze followed by a tee junction serving as gas inlet for $\mathrm{CO}$ and a stainless steel loop leading the sample air back to the inside of the TRANC. Here, the Au tube $(l=490 \mathrm{~mm}$, $\mathrm{OD}=6 \mathrm{~mm}, \mathrm{ID}=4 \mathrm{~mm}$ ), i.e. the location where the catalytic conversion occurs, is mounted. Another loop at the back end of the Au tube leads the stainless steel pipe outside the converter, where a $4 \mu \mathrm{m}$ filter and a critical orifice assure the desired pressure drop (see Sect. 2.2) before the sample air passes through lightproof tubing and enters the CLD for NO analysis. Residence time in the converter at a flow rate of $2.71 \mathrm{~min}^{-1}$ is $\sim 0.73 \mathrm{~s}$.

An operating temperature of $>800{ }^{\circ} \mathrm{C}$ is needed to fully oxidise the reduced $\mathrm{N}$ compounds (McCalley and Sparks, 2009 , Supplement). Such high temperatures also convert oxidised $\mathrm{N}$ compounds like $\mathrm{HNO}_{3}$ to lower oxidation states (Reaction 2; see e.g. Day et al., 2002). These conditions for the thermal conversion are implemented by the resistance-heated $\mathrm{FeNiCr}$ tube. A current of $80 \mathrm{~A}$ at a voltage of $5 \mathrm{~V}$ is fed to the tube over brass blocks at the two end fittings. Provision of electricity is effected by a switch-mode power supply with the temperature of the tube being regulated by a universal modulator and controlled by a thermocouple (see Fig. 1). The Au tube is indirectly warmed up to approximately $300^{\circ} \mathrm{C}$ by the waste heat of the $\mathrm{FeNiCr}$ tube. The tube lead-throughs of both the inner and outer housing are electrically insulated by ceramic material except for two small additional inlets that are connected over flexible tubes with two pumps assuring permanent ventilation and removal of hot air between the inner and the outer housing at a flux rate of $51 \mathrm{~min}^{-1}$ each (not shown in Fig. 1).

Figure 2 shows the temperature distribution inside the $\mathrm{FeNiCr}$ and the Au tube during different experimental runs. The target temperature of the heating modulator was set to $895^{\circ} \mathrm{C}$ to ensure temperatures above the desired values of 870 and $300^{\circ} \mathrm{C}$ over a significant part of the $\mathrm{FeNiCr}$ and the $\mathrm{Au}$ tube, respectively. The direct heating of the $\mathrm{FeNiCr}$ tube ensures temperatures above $100^{\circ} \mathrm{C}$ from the first millimetre of the inlet, although the target temperature is only reached in the heat-insulated part of the converter. The generally hot inner surfaces are supposed to minimise wall interaction effects for the sampled $\mathrm{N}_{\mathrm{r}}$ compounds.

\subsection{Combination of TRANC with fast-response NO analysis}

The TRANC is the key part of a comprehensive measuring system consisting of a CLD connected to a dry vacuum scroll pump (BOC Edwards XDS10, Sussex, UK) and a calibration unit (see Sect. 3.1) with a multi-gas calibrator and specific reference gases. In our setup, we used a commercial CLD (780 TR, ECO PHYSICS, Dürnten, Switzerland) for NO analysis. The measurement principle of this instrument is based on gas phase titration, i.e. the reaction of $\mathrm{NO}$ with $\mathrm{O}_{3}$. It generates electronically excited $\mathrm{NO}_{2}^{*}$ molecules, which rapidly decay to their ground state in a reduced pressure regime by emitting photons. The total light intensity in the reaction chamber, detected by a photomultiplier tube (PMT), is proportional to the NO mixing ratio (Fontijn et al., 1970; Rummel et al., 2002). To minimise electrical noise, the 


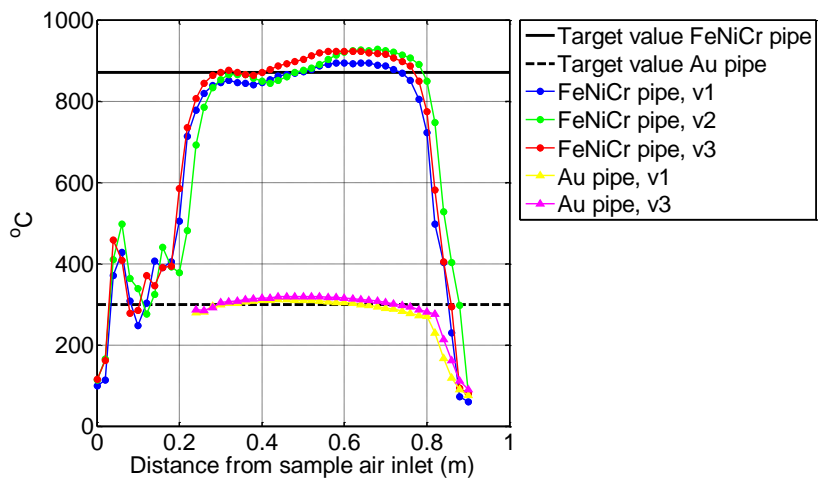

Fig. 2. Temperature distribution inside TRANC during different experimental runs with "v1", "v2", and "v3" indicating that the target temperature for the heating power modulator was set to 870,880 , and $895^{\circ} \mathrm{C}$, respectively.

temperature of the PMT is held constant at $-18^{\circ} \mathrm{C}$. Flushing with oxygen or dry air avoids condensation. An ozone generator supplies the main chamber of the CLD with $\mathrm{O}_{3}$-enriched air, where it reacts with $\mathrm{NO}$ to $\mathrm{NO}_{2}^{*}$ and $\mathrm{O}_{2}$.

To reduce the probability of energy loss of $\mathrm{NO}_{2}^{*}$ molecules by collision with others, the gas phase titration in the main chamber occurs under low pressure, i.e. $<20 \mathrm{hPa}$. This is effected by the critical orifice located at the back end of the stainless steel tube that is leaving the TRANC towards the CLD (Fig. 1) and restricts the flow to $2.71 \mathrm{~min}^{-1}$. In our setup, the instrument was running in a continuous mode, integrating the photons over $0.05 \mathrm{~s}$. In the standard operation procedure, the CLD 780TR uses so-called pre-chamber measurements in order to correct for interferences which might be caused by e.g. hydrocarbons in the sample air that react with $\mathrm{O}_{3}$ in a similar way like $\mathrm{NO}$ and are therefore detected as NO in the main reaction chamber. For fast response measurements this option is disabled. Frequent calibration aims at minimising related errors. Furthermore we estimate that the relative contribution of possible interferences is small in comparison to the $\sum \mathrm{N}_{\mathrm{r}}$ concentration. $\mathrm{As}_{3}$ is completely destroyed in the TRANC (thermal decomposition and reduction by $\mathrm{CO}$ ), chemical $\mathrm{NO}$ loss by gas phase reaction $\left(\mathrm{NO}+\mathrm{O}_{3} \rightarrow \mathrm{NO}_{2}+\mathrm{O}_{2}\right)$ could also be neglected. Even if a small amount of $\mathrm{O}_{3}$ would pass the TRANC, the influence on concentration changes are expected to be lower than the detection limit of the CLD according to Rummel et al. (2002). A schematic overview of the TRANC-CLD system in an ECsetup is given in Fig. 3.

\section{Results of performance tests}

\subsection{Calibration and conversion of individual $\mathrm{N}_{\mathrm{r}}$ compounds}

\subsubsection{General calibration and $\mathrm{NO}_{2}$ conversion}

During field application, the TRANC-CLD unit was calibrated by regularly feeding calibration gas with different $\mathrm{NO}$ and $\mathrm{NO}_{2}$ concentrations through the system (Fig. 3). In our setup, we used a multi-gas calibrator (S6100, Environics Inc., Tolland, USA) connected to two different reference gas cylinders containing $10 \mathrm{ppm} \mathrm{NO}$ and $10 \mathrm{ppm} \mathrm{NO}_{2}$ each as well as a pure air generator (PAG 003, ECO PHYSICS, Dürnten, Switzerland). The calibrator mixed the desired gas concentration by dilution of the cylinder standard with zero air. Potential loss of NO in the TRANC converter, particularly with respect to the usage of a Pt-gauze catalyst (see Kliner et al., 1997) could be excluded as no significant reduction of $\mathrm{NO}$ concentration was found when adding NO calibration gas upstream and downstream of the TRANC.

We used gas concentrations of $6,10,20$, and $50 \mathrm{ppb}$ NO as well as pure air to calibrate the TRANC-CLD system. Additionally $50 \mathrm{ppb} \mathrm{NO}_{2}$ and $50 \mathrm{ppb} \mathrm{NO}$ mixed with $\mathrm{O}_{3}$ $(<50 \mathrm{ppb})$ was given into the system to determine the conversion efficiency of $\mathrm{NO}_{2}$. During a typical calibration procedure, the calibrator started mixing the target concentration $3.5 \mathrm{~h}$ prior to the actual calibration run when the reference gas was fed into the system. At this time, the calibration valve near the TRANC inlet (Fig. 3) was still shut and the calibration gas was vented directly from the calibrator unit. After activating the TRANC valve, the system was calibrated for 30 min with one specific gas concentration. As the reference gas was fed into the tubes with a higher flow rate (approximately $51 \mathrm{~min}^{-1}$ ) than that established by the vacuum pump and the critical orifice $\left(2.71 \mathrm{~min}^{-1}\right)$, the excess gas was leaving the system through the sample air inlet at the front side of the TRANC. After 30 min the TRANC valve was switched off to set the system back to the measurement mode for ambient air. To assure a well conditioned calibration gas tube and therefore a stable calibration gas concentration at the sample air inlet of the TRANC, only data of the 10-min period from 15 to $25 \mathrm{~min}$ after the initial switch were taken to calculate the NO concentrations. If necessary, spikes were removed and the 10-min window was shifted to the most stable interval during the respective half-hour calibration period. Over the field measurement period (see Fig. 4a), not a single calibration run was observed, where the 30-min interval had to be extended and data were not discarded due to other system instabilities.

For optimal data coverage during long-term measurement campaigns, the system was configured to calibrate for $30 \mathrm{~min}$ with only one gas concentration once a night, in this case from 03:30 to 04:00 a.m LT. The data obtained in these eight consecutive nights were used for the calibration regression of 

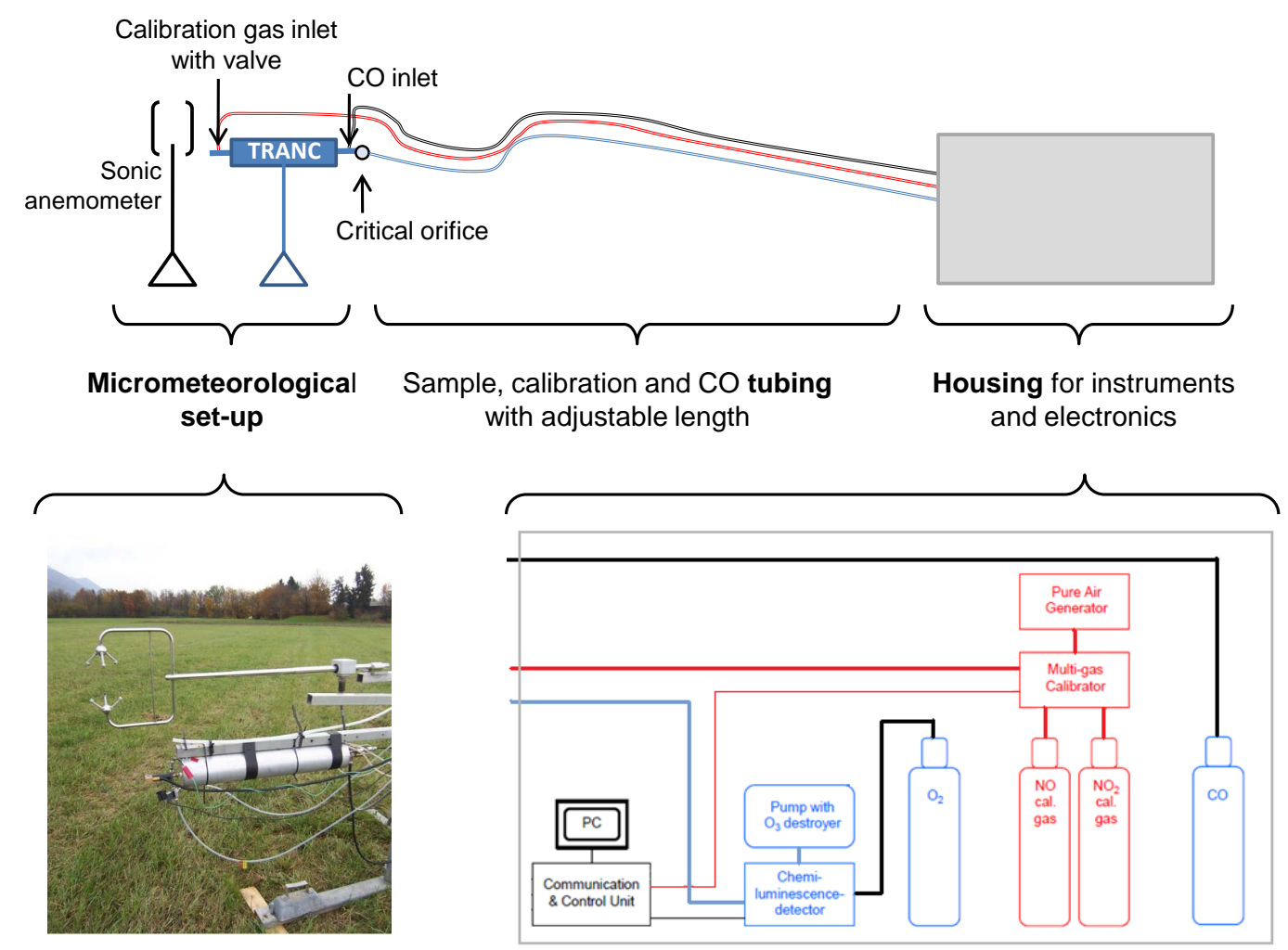

Fig. 3. Schematic overview of the TRANC-CLD system (blue) in an eddy-covariance setup. Elements of the calibration unit are shown in red. Bold lines indicate tubing. The photo shows the field-setup at the Oensingen site.

this time period. With a new calibration interval starting on day nine, the regression was updated with the data recorded from day 9 to 16 , accordingly. These steps with the respective regression update were repeated for all following 8-day periods.

A low positive NO signal slightly different from zero with a mean offset of $0.055( \pm 0.028)$ (Fig. 4b) was found while calibrating with pure air. Beside the interference with hydrocarbons in the sample air (see Sect. 2.2) or impurities in the added CO (Hegglin et al., 2006), this could have been induced by the pure air generator through a small contamination with any other $\mathrm{N}_{\mathrm{r}}$ compound. The overall calibration performance of a multi-month observation period is given in Fig. 4 (panels a and b). These data were taken from a field campaign conducted at an agricultural site in Gebesee, Germany, which will be described in more detail in Brümmer et al. (2012b). $R^{2}$ values from the correlation between the given calibration gas concentration and the corresponding CLD signals of single 8-day periods were ranging between 0.81 and 0.99 with $R^{2}=0.98$ for the averaged fit $(n=30$ for each gas concentration). In most cases, intercepts were found to be slightly positive (Fig. 4b).

Over the same 11-month observation period, we found a mean conversion efficiency for $\mathrm{NO}_{2}$ of $91 \%$ (Fig. 5) with a standard deviation of $\pm 9 \%$. It has to be considered that
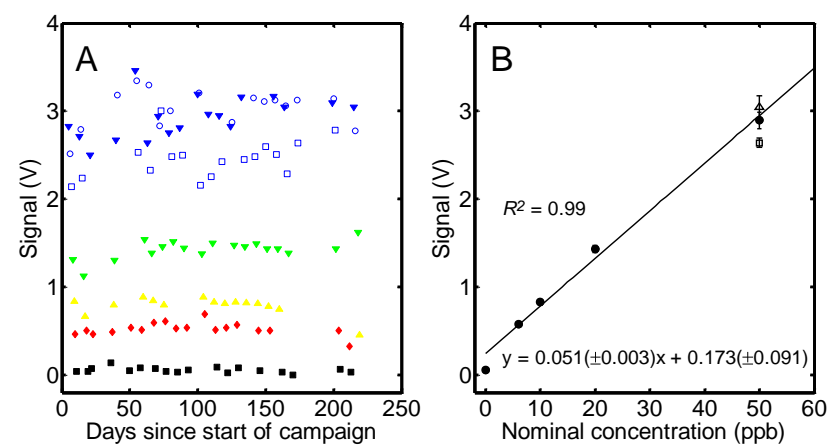

Fig. 4. Left panel: long-term stability of mean signal response of the CLD coupled to the TRANC after calibrating with different concentrations. Black squares: 0 ppb NO; red diamonds: 6 ppb NO; yellow triangles: $10 \mathrm{ppb} \mathrm{NO}$; green triangles: $20 \mathrm{ppb} \mathrm{NO}$; blue triangles: 50 ppb NO; blue open squares: 50 ppb NO 2 ; blue open circles: $50 \mathrm{ppb} \mathrm{NO}+\mathrm{O}_{3}$. DOY 0 represents 15 December 2007. Right panel: averaged signal response of left panel data plotted against nominal concentration. Data were taken from an 11-month field campaign conducted at an agricultural site in Gebesee, Germany. Each data point represents the mean of those calibration runs shown in the left panel. Error bars indicate the standard error of the mean. Filled symbols are $\mathrm{NO}$ calibrations, open square and open triangle are $\mathrm{NO}_{2}$ and $\mathrm{NO}+\mathrm{O}_{3}$ calibration runs, respectively. 


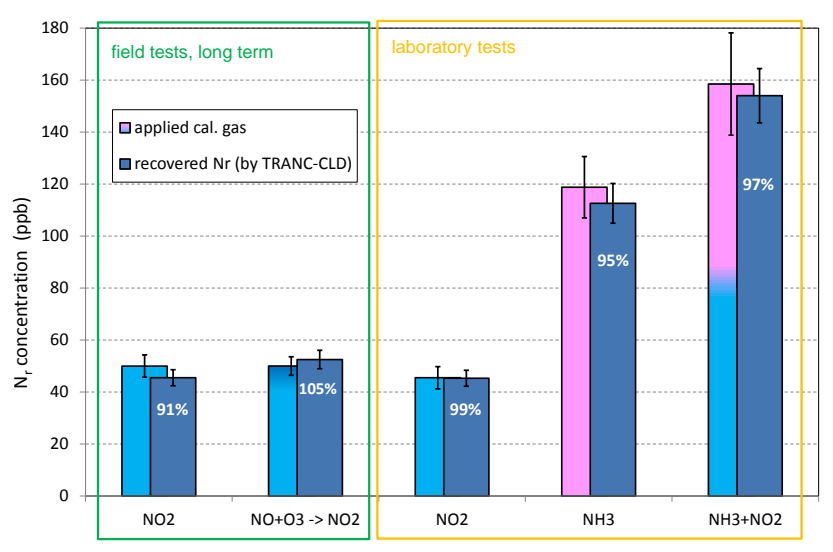

Fig. 5. Conversion efficiency tests with applied calibration gas concentrations and resulting measurements (recovered $\mathrm{N}_{\mathrm{r}}$ ) by the TRANC-CLD system under field and laboratory conditions. Error bars $(2 \sigma)$ were estimated from uncertainties in calibration (gas standards, mass flow controllers used for dilution, etc.) of the different instruments and signal noise.

cylinder calibration standards for $\mathrm{NO}_{2}$ are generally less accurate than for NO, because of possible non-ideal mixing in the gas cylinder over longer periods. The conversion rate for in-situ produced $\mathrm{NO}_{2}$, resulting from $50 \mathrm{ppb} \mathrm{NO}$ mixed with $\mathrm{O}_{3}$, was found to be $105 \%$. We observed no correlation between any of the conversion efficiencies and meteorological parameters like air temperature, relative humidity, wind speed and direction, or precipitation events as an effect of possibly poor heat insulation.

\subsubsection{Recovery rates of $\mathrm{NH}_{3}$ and mixed sample gas $\left(\mathrm{NO}_{2}\right.$ and $\left.\mathrm{NH}_{3}\right)$}

Since the preparation of reliable and accurate calibration gas mixtures for reactive nitrogenous gases is generally difficult, we concentrated the conversion efficiency tests for the TRANC on $\mathrm{NO}_{2}$ and $\mathrm{NH}_{3}$, the most abundant oxidized and reduced $\mathrm{N}_{\mathrm{r}}$ compounds, respectively, in central Europe (see e.g. Hesterberg et al., 1996; Flechard et al., 2011). The conversion of $\mathrm{NH}_{3}, \mathrm{NO}_{2}$ and a mixture of both gases was tested by parallel sampling of calibration gases by the TRANC-CLD system and specific $\mathrm{NH}_{3}$ and $\mathrm{NO}_{2}$ analysers. The $\mathrm{NH}_{3}$ analyser (Picarro G1103, Sunnyvale, CA, USA) was calibrated prior to the measurements using a permeation oven manufactured by LN Industries (Geneva, Switzerland) equipped with a $\mathrm{NH}_{3}$ permeation tube (VICI, Metronics Inc., Poulsbo, WA, USA). The permeation system was calibrated by directing the gas mixture through an impinger containing acidic solution $\left(\mathrm{H}_{2} \mathrm{SO}_{4}, 0.01 \mathrm{ml}^{-1}\right)$ and subsequent analysis by ion chromatography. The $\mathrm{NO}_{2}$ analyser (Thermo Environment chemiluminescence $\mathrm{NO}-\mathrm{NO}_{2}-\mathrm{NO}_{\mathrm{x}}$ analyser, $42 \mathrm{C}$ Trace Level, called TEI hereafter), a chemiluminescence detector, in principle operating identical to the CLD described earlier but containing an additional channel for $\mathrm{NO}_{2}$ measurements

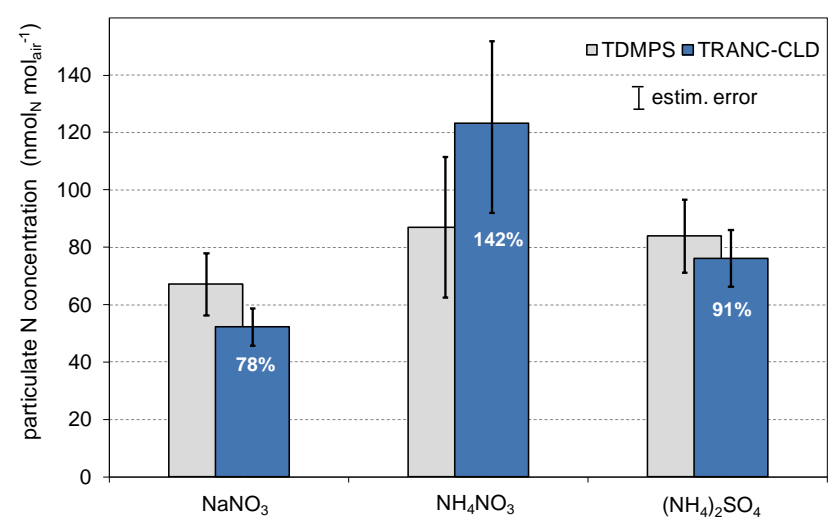

Fig. 6. Conversion tests of particulate $\mathrm{N}_{\mathrm{r}}$-compounds. Columns give the mean $\mathrm{N}_{\mathrm{r}}$ concentrations as estimated from particle number size distribution (TDMPS) and TRANC-CLD measurements. Error bars are estimated from instrument error, signal stability, background $\mathrm{N}_{\mathrm{r}}$ concentration, and (only for $\mathrm{NH}_{4} \mathrm{NO}_{3}$ ) particle evaporation.

making use of a $\mathrm{NO}_{2}$ specific photolytic converter (blue light converter BLC, Air Quality Design Inc., Wheatridge, USA; see e.g. Pollack et al., 2010) was calibrated with a NO standard parallel to the CLD. Both instruments thus agreed in NO concentrations. The conversion efficiency of the build-in $\mathrm{NO}_{2}$ converter of the TEI was determined during an instrument service just after the conversion tests.

Conversion tests for $\mathrm{NH}_{3}$ were performed by comparing the TRANC-CLD signal to $\mathrm{NH}_{3}$ concentrations as determined by the $\mathrm{NH}_{3}$ analyser. Both instruments sampled at the overflow of the same calibration tube which was flushed with the calibration gas for $48 \mathrm{~h}$ to ensure a stable $\mathrm{NH}_{3}$ concentration. The TRANC-CLD system found $112.6 \pm 0.7 \mathrm{ppb}$ $\mathrm{N}_{\mathrm{r}}$, which corresponds to a conversion efficiency of $95 \%$ compared to $\mathrm{NH}_{3}$ concentrations of $118.8 \pm 0.6 \mathrm{ppb}$. Using the same setup for $\mathrm{NO}_{2}$, the conversion efficiency was observed to be larger than $99 \%$ with $45.3 \pm 0.4 \mathrm{ppb}$ detected by the TRANC-CLD system in comparison to $45.5 \pm 0.3 \mathrm{ppb}$ $\mathrm{NO}_{2}$. Finally, a mixture of $\mathrm{NH}_{3}$ and $\mathrm{NO}_{2}$ calibration gas was fed to the analysers (see Fig. 5). To ensure excellent conditioning of the calibration tube, it was flushed with $\mathrm{NH}_{3}$ calibration gas for 3 days, adding the $\mathrm{NO}_{2}$ calibration gas after 2 days. The calibration gas mixture showed a $\mathrm{NO}_{2}$ concentration of $88.8 \pm 0.4 \mathrm{ppb}$ and an $\mathrm{NH}_{3}$ concentration of $69.7 \pm 0.4 \mathrm{ppb}$ (mean values \pm standard deviation after 1 and 3 days of tube conditioning). The TRANC-CLD system found $154.0 \pm 0.9 \mathrm{ppb}$ corresponding to a recovery rate of $97 \%$. The uncertainty of the TRANC conversion efficiency not only depends on the precision of the individual measurements (indicated by the standard deviations) but also on the absolute accuracy of the independent measurement systems. The latter is limited by the absolute uncertainty of the calibration gas source and dilution leading to total absolute $(2 \sigma)$ errors in the order of $10 \%$ (see error bars in Fig. 5). 

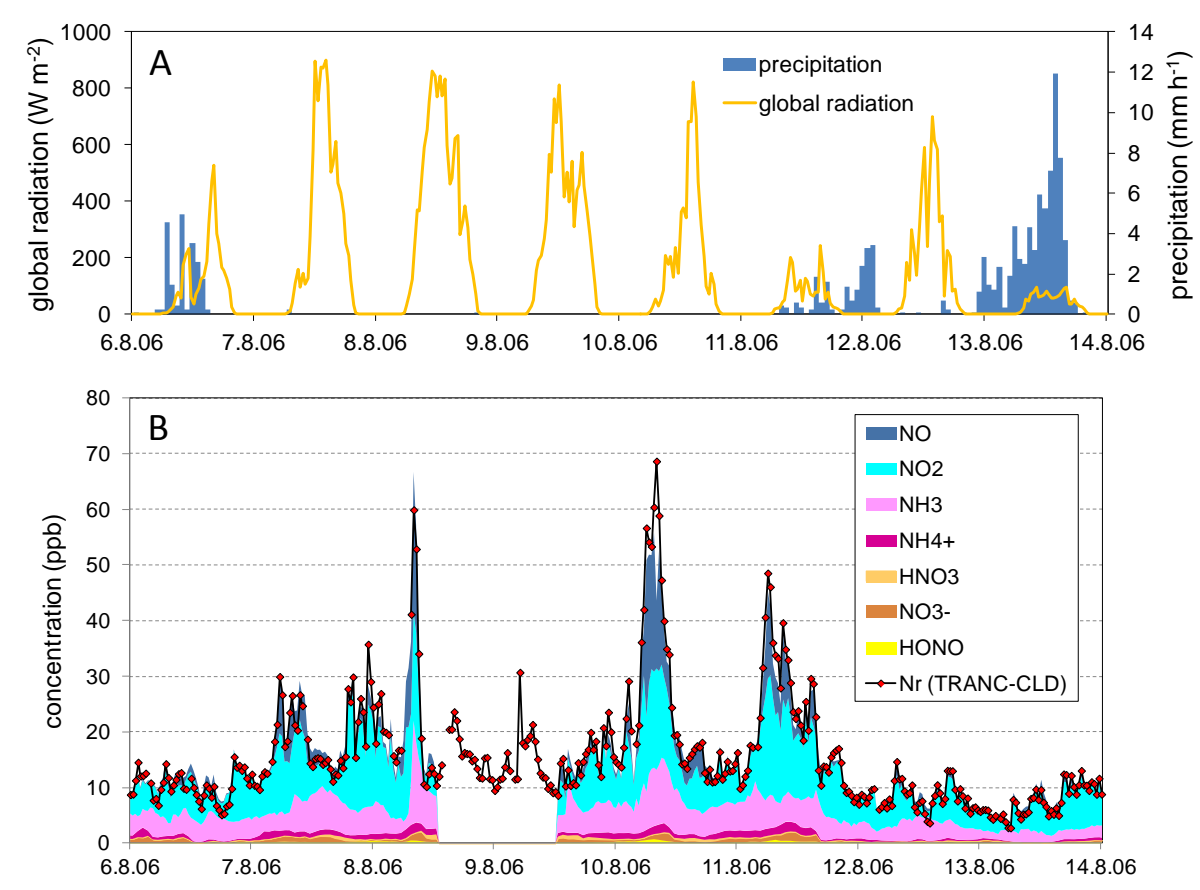

Fig. 7. Time series of (A) global radiation and precipitation and (B) concentrations of individual $\mathrm{N}_{\mathrm{r}}$ compounds (cumulative) at the Oensingen site and of the $\sum \mathrm{N}_{\mathrm{r}}$ concentration detected by the fast response TRANC-CLD system. All values were aggregated to 30 min means. For the minor compounds $\mathrm{NH}_{4}^{+}, \mathrm{HNO}_{3}, \mathrm{NO}_{3}^{-}$, and $\mathrm{HONO}$, few data gaps of 0.5 to $4 \mathrm{~h}$ length have been filled by linear interpolation.

\subsubsection{Aerosol particle conversion tests}

Aerosol particle conversion efficiency of the TRANC was tested in cooperation with the Institute for Tropospheric Research (IfT), Leipzig, Germany. Aerosol particles were generated using a collision-type atomizer (TSI, St. Paul, USA) with a $0.3 \mathrm{~mm}$ nozzle from aqueous solutions of either $\mathrm{NaNO}_{3}, \mathrm{NH}_{4} \mathrm{NO}_{3}$, or $\left(\mathrm{NH}_{4}\right)_{2} \mathrm{SO}_{4}\left(0.5 \mathrm{gl}^{-1}, 1 \mathrm{gl}^{-1}\right.$, $0.5 \mathrm{~g} \mathrm{l}^{-1}$, respectively), the three most common nitrogen containing aerosol compounds (e.g. Wexler and Seinfeld, 1991; Nemitz et al., 2009). The aerosol particles were dried and flushed into a stainless steel chamber of $1 \mathrm{~m}^{3}$, which was kept at ambient pressure. From this chamber, samples were taken in parallel by the TRANC-CLD system and a twin differential mobility particle sizer (TDMPS, Birmili et al., 1999), consisting of a differential mobility analyser combined with a condensational particle counter (UCPC3025 and CPC3010, TSI, St. Paul, USA). The recorded particle size and number distribution were used in combination with the known salt solid state densities to derive salt mixing ratios and consequently particle-bound $\mathrm{N}_{\mathrm{r}}$ mixing ratios in the chamber air. The latter were compared to the $\sum \mathrm{N}_{\mathrm{r}}$ measured by the TRANC-CLD system (Fig. 6). The results indicate mean apparent conversion efficiencies of $78 \%, 142 \%$ and $91 \%$, respectively. While the results show reasonably quantitative conversion of $\mathrm{NaNO}_{3}$ and $\left(\mathrm{NH}_{4}\right)_{2} \mathrm{SO}_{4}, \mathrm{NH}_{4} \mathrm{NO}_{3}$ seems to be either overestimated by the TRANC-CLD or underestimated by the TDMPS. In contrast to the other two aerosol species,
$\mathrm{NH}_{4} \mathrm{NO}_{3}$ is semi-volatile under ambient conditions, forming a thermodynamic equilibrium with gaseous $\mathrm{NH}_{3}$ and $\mathrm{HNO}_{3}$ (Stelson et al., 1979; Mozurkewich, 1993; Seinfeld and Pandis, 2006). For normal chamber air conditions (temperature of about $20^{\circ} \mathrm{C}$ and relative humidity of about $50 \%$ ), the gaseous $\mathrm{NH}_{3}$ and $\mathrm{HNO}_{3}$ fraction may be significant. While the TRANC-CLD system would detect both, the gas and the aerosol phase, the evaporation of gaseous $\mathrm{NH}_{3}$ and $\mathrm{HNO}_{3}$ diminish the particle mass, measured by the TDMPS. Further differences between TDMPS and TRANC-CLD system may be caused by the use of ambient air to flush the chamber and to transport the generated aerosol. This led to a relatively high and variable $\mathrm{N}_{\mathrm{r}}$ background (20 to $39 \mathrm{ppb}$ ) in the TRANC-CLD measurements, for which only an approximate correction was possible.

\subsection{Field test with ambient $\mathrm{N}_{\mathrm{r}}$ composition}

In summer 2006, an intensive field campaign within the $\mathrm{Ni}$ troEurope project allowed an in-field comparison between the concentrations of a variety of $\mathrm{N}_{\mathrm{r}}$ compounds and the $\sum \mathrm{N}_{\mathrm{r}}$ concentration measured by the TRANC-CLD system. The study took place in Central Switzerland, close to the village of Oensingen at an intensively managed grassland site. A detailed site description can be found in Ammann et al. (2009).

During this study $\mathrm{NO}$ and $\mathrm{NO}_{2}$ were measured by a TEI chemiluminescence analyser in combination with a BLC 


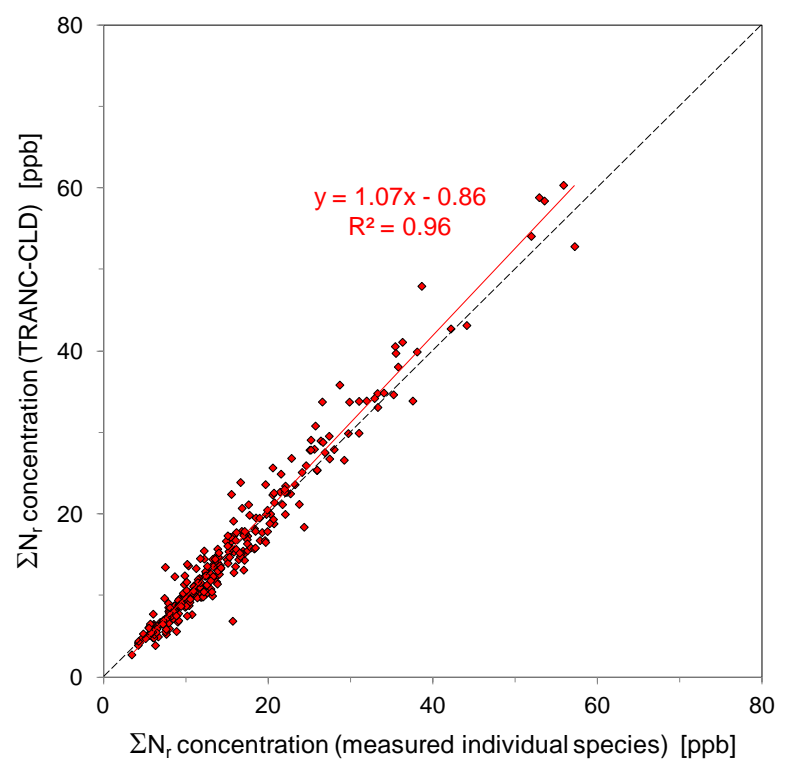

Fig. 8. Comparison between $\sum N_{r}$ concentrations detected by the TRANC-CLD system and as the sum of measured individual species (acc. to Table 1) at the Oensingen field site during August 2006. Only those cases were included, for which measurements of all species ( $30 \mathrm{~min}$ means) were available. The solid line indicates the calculated linear regression (with corresponding equation), and the dashed line indicates the 1:1 line.

photolytic converter (see Sect. 3.1.2), and gaseous $\mathrm{NH}_{3}$, $\mathrm{HNO}_{3}$, and $\mathrm{HONO}$ as well as particulate $\mathrm{NH}_{4}^{+}$, and $\mathrm{NO}_{3}^{-}$ were measured using the GRadient of AErosol and Gases Online Registrator (GRAEGOR, Thomas et al., 2009) - a wet chemical instrument, sampling with a wet annular denuder steam jet aerosol collector combination, coupled to online analysis by ion-chromatography $\left(\mathrm{HNO}_{3}, \mathrm{HONO}, \mathrm{NO}_{3}^{-}\right)$and flow injection analysis $\left(\mathrm{NH}_{3}, \mathrm{NH}_{4}^{+}\right)$. Furthermore, $\mathrm{NH}_{3}$ was measured additionally by a wet chemical AiRRmonia instrument (Erisman et al., 2001; Spirig et al., 2010; Flechard et al., 2010) (Table 1). Time series of $\mathrm{NH}_{3}$ measured by the AiRRmonia system, gap-filled $\mathrm{HNO}_{3}, \mathrm{HONO}, \mathrm{NH}_{4}^{+}, \mathrm{NO}_{3}^{-}$ data of the GRAEGOR, and $\mathrm{NO}, \mathrm{NO}_{2}$ data of the TEI are shown in Fig. 7. The exemplary time series reveal distinct fluctuations of the different $\mathrm{N}_{\mathrm{r}}$ compounds as well as the large dominance of $\mathrm{NH}_{3}$ and $\mathrm{NO}_{2}$, accounting for more than $75 \%$ of the site's ambient $\sum \mathrm{N}_{\mathrm{r}}$ concentration. The observed variability is related to the weather conditions with generally low concentrations in the rainy periods and also to the diurnal cycle with e.g. peak NO concentrations in the morning hours (due to the traffic source, limited vertical mixing and low ozone concentrations). The TRANC-CLD results compare very well to the sum of the individual measurements, capturing its fluctuations independently of the contribution of the different $\mathrm{N}_{\mathrm{r}}$ species. A quantitative comparison between the two approaches for the $\sum \mathrm{N}_{\mathrm{r}}$ concentration is shown in Fig. 8. The data points are generally close

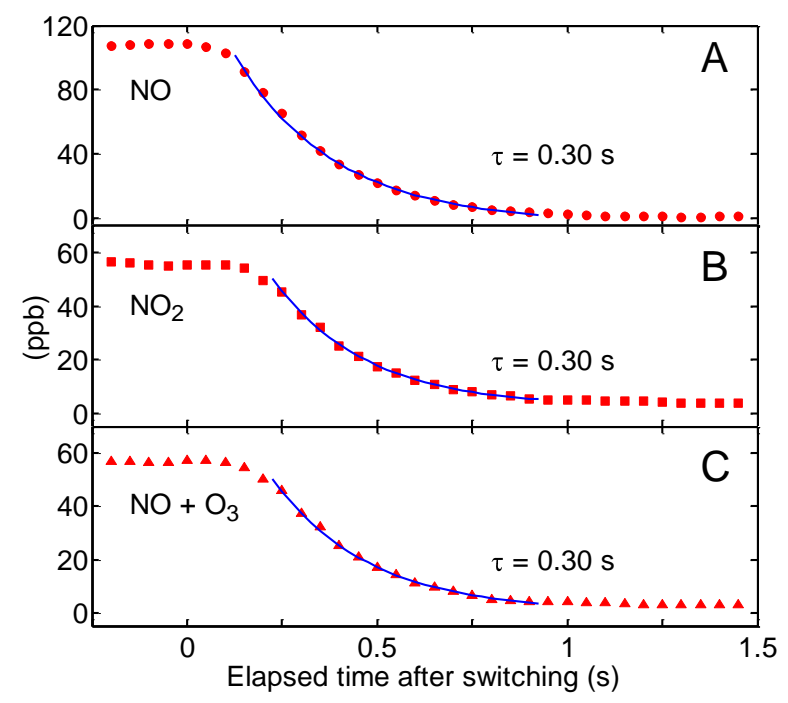

Fig. 9. Time response of the TRANC-CLD system characterising rapid step concentration changes. The course of the curve can be best approximated by exponential decay functions in the form of $c(t)=\Delta c \cdot e^{-t / \tau}+c_{\text {final }}$ with response (e-folding) times of $\tau=0.30 \mathrm{~s}$ for $\mathrm{NO}, \mathrm{NO}_{2}$ and $\mathrm{NO}+\mathrm{O}_{3}$.

to the 1:1 line indicating an overall good agreement with slightly higher values by TRANC-CLD method (linear regression slope of $1.07 \pm 0.013$ ). The small systematic deviation can either result from missing $\mathrm{N}_{\mathrm{r}}$ compounds in the individual measurements (organic nitrogenous compounds like e.g. PAN, MPAN, acetonitrile etc.) or combined calibration errors for the various analyser systems. Yet, there is no indication of a significant lack of conversion efficiency in the TRANC system under the varying field conditions.

\subsection{Time response}

An important feature for a converter designed for EC measurements is the fast detection of rapidly changing gas concentrations. Thus, we checked the TRANC-CLD system for time response characteristics during the calibration periods (Sect. 3.1.1) to make sure that even fast variations are clearly determined by the CLD without major attenuation effects. Figure 9a shows the time response of the NO signal in ppb recorded at a rate of $20 \mathrm{~Hz}$ after switching the TRANC valve from the calibration mode back to ambient air, which in that case was about $5 \mathrm{ppb}$. The course of the curve can be best approximated by an exponential decay function in the form of $c(t)=\Delta c \cdot e^{-t / \tau}+c_{\text {final }}$ with a response (e-folding) time of $\tau=0.30 \mathrm{~s}$. The full step change was completed within about $1 \mathrm{~s}$ after switching the valve. Figure $9 \mathrm{~b}$ and $\mathrm{c}$ show the time response of the $\mathrm{NO}$ signal recorded after switching the TRANC valve from the $\mathrm{NO}_{2}$ and the $\mathrm{NO}$ plus $\mathrm{O}_{3}$ calibration mode, respectively, back to ambient air. Here, $\tau$ values of $0.30 \mathrm{~s}$ were found as well. These numbers demonstrate the fast conversion and time response of the TRANC-CLD 
Table 1. Overview of the instruments used for concentration measurements of nitrogenous compounds during the field inter-comparison in Oensingen, August 2006.

\begin{tabular}{lclll}
\hline Quantity & $\begin{array}{c}\text { Oxidation } \\
\text { level }\end{array}$ & Instruments & Detection principle & $\begin{array}{l}\text { Observed } \\
\text { concentration range }\end{array}$ \\
\hline $\mathrm{NO}$ & +2 & ThermoElectron 42C & Chemiluminescence & $0-28 \mathrm{ppb}$ \\
\hline $\mathrm{NO}_{2}$ & +4 & $\begin{array}{l}\text { ThermoElectron } 42 \mathrm{C} \\
\text { +blue light converter }\end{array}$ & $\begin{array}{l}\text { Photolytic conversion } \\
+ \text { chemiluminescence }\end{array}$ & $1-22 \mathrm{ppb}$ \\
\hline $\mathrm{NH}_{3}$ & -3 & AiRRmonia & $\begin{array}{l}\text { Membrane scrubber } \\
+ \text { conductivity cell }\end{array}$ & $1-19 \mathrm{ppb}$ \\
\hline $\mathrm{pNH}_{4}^{+}$ & -3 & GRAEGOR & $\begin{array}{l}\text { Mist chamber + flow } \\
\text { injection/conductivity }\end{array}$ & $0-1.9 \mathrm{ppb}$ \\
\hline $\mathrm{HNO}_{3}$ & +5 & GRAEGOR & $\begin{array}{l}\text { Rotating denuder } \\
+ \text { ion chromatography }\end{array}$ & $0-0.8 \mathrm{ppb}$ \\
\hline $\mathrm{pNO}_{3}^{-}$ & +5 & GRAEGOR & $\begin{array}{l}\text { Mist chamber } \\
+ \text { ion chromatography }\end{array}$ & $0-1.7 \mathrm{ppb}$ \\
\hline $\mathrm{HONO}$ & +3 & GRAEGOR & $\begin{array}{l}\text { Rotating denuder } \\
+ \text { ion chromatogrphy }\end{array}$ & $0-0.8 \mathrm{ppb}$ \\
\hline$\sum \mathrm{N}_{\mathrm{r}}$ & -3 to +5 & TRANC-CLD & $\begin{array}{l}\text { Thermal and catalytic } \\
\text { conversion }+\end{array}$ & $0-69 \mathrm{ppb}$ \\
& & & chemiluminescence & \\
\hline
\end{tabular}

system. In another experiment (data not shown), two different NO concentrations were prepared and alternately fed into the system, one by the multi-gas calibrator and the other directly from the gas cylinder. In this test, we found e-folding times of $0.35 \mathrm{~s}$. Given the fact, that the average residence time of air in the CLD reaction chamber $(V=0.71$ at a pressure of $20 \mathrm{mbar}$ and a flowrate of $3 \mathrm{sl} \mathrm{min}^{-1}$ ) is $0.28 \mathrm{~s}$, the reaction time is largely limited by the flushing of the CLD reaction chamber with probably some additional longitudinal mixing due to the flow velocity profile within the tube.

\section{Discussion and conclusions}

High-frequency measurements of $\mathrm{N}_{\mathrm{r}}$ species have been rarely conducted in land-atmosphere exchange research and were usually limited to selected sites and short field campaigns. Neither a robust measurement technique for the longterm monitoring of $\sum \mathrm{N}_{\mathrm{r}}$ nor a technique that is fast enough to be applicable for EC measurements has been engineered and field-tested up to now. With the development of the TRANC, we present a unique methodology for both quantifying $\sum \mathrm{N}_{\mathrm{r}}$ and a device being robust and fast enough to be usable in an EC setup when combined with a fast response NO detector (CLD).

The specific design of the TRANC which features fast and strong heating of the sample gas and quick conversion of $\mathrm{N}_{\mathrm{r}}$ compounds to NO allows the detection of polar, water soluble and sticky substances like $\mathrm{NH}_{3}$, avoiding e.g. water surface effects (Kita et al., 2006; Sintermann et al., 2011). As the NO resulting from the conversion is relatively inert (in the absence of $\mathrm{NO}_{2}$ and $\mathrm{O}_{3}$ ) it permits the use of long tubing between the TRANC and the analyser system and thus an installation of the TRANC on masts and towers for micrometeorological measurements. Other arising problems when using long tubing such as the correct determination of the lag time (to maximise the covariance), i.e. the time the air sample needs from entering the converter until it reaches the analyser, or possible high-frequency damping will be addressed in Ammann et al. (2012).

Testing recovery rates for single $\mathrm{N}_{\mathrm{r}}$ compounds during laboratory tests, we found values of 95 and $99 \%$ for $\mathrm{NH}_{3}$ and $\mathrm{NO}_{2}$, respectively, and $97 \%$ when the two gases were combined. In-field longterm stability was approved by repeated conversion tests for $\mathrm{NO}_{2}$ with an average value of $91 \%$. These conversion efficiency results were not significantly different from $100 \%$. For particulate mineral N, the laboratory conversion tests showed a less clear picture with more uncertain conversion efficiencies. However, while too many unknowns limit the possibility to explain all differences in the measurements, the overall qualitative picture (cf. Fig. 6) indicates an effective conversion of the aerosol particle $\mathrm{N}$ to NO in the TRANC.

The conversion efficiencies of the TRANC are comparable to values observed in other studies. McCalley and Sparks (2009), for example, report on $86 \%$ for $\mathrm{NH}_{3}$ measured with their converter system and $100 \%$ for $\mathrm{NO}_{2}$. Horii et al. (2004) compared concentrations of $\mathrm{NO}_{2}$ obtained by TDLAS versus photolysis-chemiluminescence instruments and found a slope of $1.1 \pm 0.2$ with a $R^{2}$ of 0.91 . The TD-LIF instrument presented by Farmer et al. (2006) was tested by 
Thornton et al. (2003) and Rosen et al. (2004) with a conversion efficiency of $>95 \%$ for $\mathrm{NO}_{2}$ and $>94 \%$ for $\sum \mathrm{PN}$ using photolysis-chemiluminescence and gas chromatographs equipped with electron capture detectors, respectively, for comparative measurements. McCalley and Sparks also found a $100 \%$ transformation for HONO, however only 78 to $99 \%$ for $\mathrm{NO}_{\mathrm{y}}\left(\mathrm{PAN}\right.$, alkyl nitrate, $\mathrm{HNO}_{3}$ and other forms of $\mathrm{NO}_{\mathrm{y}}$ ). Kliner et al. (1997) also used a Au catalyst to convert $\mathrm{NO}_{\mathrm{y}}$ compounds to NO and discovered a gas-phase process that contributes to a more readily conversion of $\mathrm{HNO}_{3}$ than e.g. $\mathrm{NO}_{2}$. Furthermore, they investigated some non- $\mathrm{NO}_{\mathrm{y}}$ species (reduced $\mathrm{N}_{\mathrm{r}}$ species) such as hydrogen cyanide $(\mathrm{HCN})$ and acetonitrile $\left(\mathrm{CH}_{3} \mathrm{CN}\right)$ for potential interferences in the $\mathrm{NO}_{\mathrm{y}}$ detection scheme. They found an almost full conversion of $\mathrm{HCN}$ and a partial conversion ( $\sim 40$ to $65 \%)$ of $\mathrm{CH}_{3} \mathrm{CN}$ at $300^{\circ} \mathrm{C}$. In the TRANC with the additional $870{ }^{\circ} \mathrm{C}$ unit we expect a full conversion of all organic $\mathrm{N}_{\mathrm{r}}$ compounds. In Kliner et al. (1997) and also in a similar study by Fahey et al. (1985), $\mathrm{N}_{2} \mathrm{O}$ conversion was found to be negligible. In our tests, we performed an in-field comparison between the sum of individually measured $\mathrm{NO}, \mathrm{NO}_{2}, \mathrm{NH}_{3}, \mathrm{HNO}_{3}, \mathrm{HONO}, \mathrm{NH}_{4}^{+}$, $\mathrm{NO}_{3}^{-}$by commercially available systems and the $\sum \mathrm{N}_{\mathrm{r}}$ concentration by TRANC-CLD. Excellent agreement was found in the temporal course $\left(R^{2}=0.96\right)$ with the TRANC showing on average slightly (7\%) higher values. This small systematic difference might be due to minor $\mathrm{N}_{\mathrm{r}}$ compounds not measured individually (e.g. organic compounds like PAN) or small errors in the calibration of any of the used analysers. The concentrations of $\mathrm{HONO}$ and $\mathrm{HNO}_{3}$, for which we did not explicitly check the conversion efficiency, were very small during the field experiment and thus their contribution to the $\sum \mathrm{N}_{\mathrm{r}}$ measurements by the TRANC was not statistically significant. However, based on previous reports in the literature (e.g. Fahey et al., 1985; McCalley and Sparks, 2009) we assume that they were nearly fully converted under the conditions in the TRANC.

Regarding the response time for step concentration changes, we determined e-folding times of $\leq 0.35 \mathrm{~s}$ during different laboratory and field tests. As this value is in large part influenced by the flushing of the CLD chamber, it demonstrates that the TRANC is able to quickly and accurately detect the variability in $\sum \mathrm{N}_{\mathrm{r}}$ concentrations. For a similar system with a lower flow rate that was used for $\mathrm{NO}_{\mathrm{y}}$ deposition measurements over a 24-m high forest Munger et al. (1996) found an e-folding time of less than $1 \mathrm{~s}$.

The usage of the TRANC-CLD system within an EC setup allows for the determination of the net ecosystem exchange of $\sum \mathrm{N}_{\mathrm{r}}$ continuously over longer periods, thereby providing a parameter of major interest when assessing the productivity of ecosystems by its nutrient $\mathrm{N}$ input. Also, there is no need to correct for chemical interactions and phase changes of the $\mathrm{N}_{\mathrm{r}}$ compounds, keeping the measurements at a relatively low maintenance and reasonable cost level. However, one of the major benefits of the TRANC is at the same time one of its biggest constraints, i.e. the fact, that it can only measure $\sum \mathrm{N}_{\mathrm{r}}$ (or net $\mathrm{N}_{\mathrm{r}}$ exchange) and a differentiation into single $\mathrm{N}_{\mathrm{r}}$ compounds is not possible with one converter system. But even for process studies and mechanistic modeling, the $\sum \mathrm{N}_{\mathrm{r}}$ measurement can provide important constraints and validation data in combination with additional selective converters or detectors.

Acknowledgements. This work was supported by the EU project NitroEurope-IP (Contract 017841) under the EC 6th Framework Program for Research and Technological Development and by the Swiss State Secretariat for Education and Research (Project No. C09.0028) under the framework of the COST action ABBA (ES0804). We would like to thank the Max Planck Institute (MPI) for Biogeochemistry in Jena, Germany, the MPI for Chemistry in Mainz (esp. Ivonne Trebs), Germany, the University of Bayreuth, Germany, and the Institute for Tropospheric Research, Leipzig, Germany for supporting lab and field tests during the development of the TRANC within their experiments. We also gratefully acknowledge the technical support by Dirk Lempio and Catharina Don.

Edited by: F. X. Meixner

\section{References}

Ammann, C., Spirig, C., Leifeld, J., and Neftel, A.: Assessment of the nitrogen and carbon budget of two managed temperate grassland fields, Agr. Ecosyst. Environ., 133, 150-162, 2009.

Ammann, C., Wolff, V., Marx, O., Brümmer, C., and Neftel, A.: Measuring the biosphere-atmosphere exchange of total reactive nitrogen by eddy covariance, Biogeosciences Discuss., accepted, 2012.

Baldocchi, D. D., Falge, E., Gu, L., Olson, R., Hollinger, D., Running, S., Anthoni, P., Bernhofer, C., Davis, K., Evans, R., Fuentes, J., Goldstein, A., Katul, G., Law, B. E., Lee, X., Malhi, Y., Meyers, T., Munger, W., Oechel, W., Paw U, K. T., Pilegaard, K., Schmid, H. P., Valentini, R., Verma, S., Vesala, T., Wilson, K., and Wofsy, S. C.: FLUXNET: A new tool to study the temporal and spatial variability of ecosystem-scale carbon dioxide, water vapor and energy flux densities, B. Am. Meteorol. Soc., 82, 2415-2434, 2001.

Birmili, W., Stratmann, F., and Wiedensohler, A.: Technical note Design of a DMA-based size spectrometer for a large particle size range and stable operation, J. Aerosol Sci., 30, 549-553, 1999.

Brümmer, C., Black, T. A., Jassal, R. S., Grant, N. J., Spittlehouse, D. L., Chen, B., Nesic, Z., Amiro, B. D., Arain, M. A., Barr, A. G., Bourque, C. P. A., Coursolle, C., Dunn, A. L., Flanagan, L. B., Humphreys, E. R., Lafleur, P. M., Margolis, H. A., McCaughey, J. H., and Wofsy, S. C.: How climate and vegetation type influence evapotranspiration and water use efficiency in Canadian forest, peatland and grassland ecosystems, Agr. Forest Meteorol., 153, 14-30, 2012a.

Brümmer, C., Marx, O., Kutsch, W., Ammann, C., Wolff, V., and Freibauer, A.: Fluxes of total reactive atmospheric nitrogen using eddy covariance above arable land, to be submitted, 2012b. 
Coursolle, C., Margolis, H. A., Barr, A. G., Black, T. A., Amiro, B. D., McCaughey, J. H., Flanagan, L. B., Lafleur, P. M., Roulet, N. T., Bourque, C. P. A., Arain, M. A., Wofsy, S. C., Dunn, A., Morgenstern, K., Orchansky, A. L., Bernier, P. Y., Chen, J. M., Kidston, J., Saigusa, N., and Hedstrom, N.: Late-summer carbon fluxes from Canadian forests and peatlands along an east-west continental transect, Can. J. Forest Res., 36, 783-800, 2006.

Dämmgen, U. and Zimmerling, R.: Vertical fluxes of air-borne acidifying and eutrophying species in the Schorfheide Nature Reserve in Brandenburg, Germany, J. Appl. Bot., 76, 190-202, 2002.

Day, D. A., Wooldridge, P. J., Dillon, M. B., Thornton, J. A., and Cohen, R. C.: A thermal dissociation laser-induced fluorescence instrument for in situ detection of NO2, peroxy nitrates, alkyl nitrates, and $\mathrm{HNO}_{3}$, J. Geophys. Res., 107, 4046, doi:10.1029/2001JD000779, 2002.

Denmead, O. T., MacDonald, B. C. T., Bryant, G., Naylor, T., Wilson, S., Griffith, D. W. T., Wang, W. J., Salter, B., White, I., and Moody, P. W.: Emissions of methane and nitrous oxide from Australian sugarcane soils, Agr. Forest Meteorol., 150, 748-756, 2010.

Erisman, J. W., Otjes, R., Hensen, A., Jongejan, P., van den Bulk, P., Khlystov, A., Mols, H., and Slanina, S.: Instrument development and application in studies and monitoring of ambient ammonia, Atmos. Environ., 35, 1913-1922, 2001.

Erisman, J. W., Bleeker, A., Galloway, J., and Sutton, M. A.: Reduced nitrogen in ecology and the environment, Environ. Pollut., 150, 140-149, 2007.

Fahey, D. W., Eubank, C. S., Hubler, G., and Fehsenfeld, F. C.: Evaluation of a catalytic reduction technique for the measurement of total reactive odd-nitrogen $\mathrm{NO}_{\mathrm{y}}$ in the atmosphere, J. Atmos. Chem., 3, 435-468, 1985.

Famulari, D., Fowler, D., Hargreaves, K., Milford, C., Nemitz, E., Sutton, M., and Weston, K.: Measuring eddy covariance fluxes of ammonia using tunable diode laser absorption spectroscopy, Water Air Soil Poll., Focus, 4, 151-158, 2004.

Farmer, D. K., Wooldridge, P. J., and Cohen, R. C.: Application of thermal-dissociation laser induced fluorescence (TD-LIF) to measurement of $\mathrm{HNO}_{3}$, alkyl nitrates, peroxy nitrates, and $\mathrm{NO}_{2}$ fluxes using eddy covariance, Atmos. Chem. Phys., 6, 3471-3486, doi:10.5194/acp-6-3471-2006, 2006.

Flechard, C. R. and Fowler, D.: Atmospheric ammonia at a moorland site. II: Long-term surface-atmosphere micrometeorological flux measurements, Q. J. Roy. Meteor. Soc., 124, 759-791, 1998.

Flechard, C. R., Spirig, C., Neftel, A., and Ammann, C.: The annual ammonia budget of fertilised cut grassland - Part 2: Seasonal variations and compensation point modeling, Biogeosciences, 7 , 537-556, doi:10.5194/bg-7-537-2010, 2010.

Flechard, C. R., Nemitz, E., Smith, R. I., Fowler, D., Vermeulen, A. T., Bleeker, A., Erisman, J. W., Simpson, D., Zhang, L., Tang, Y. S., and Sutton, M. A.: Dry deposition of reactive nitrogen to European ecosystems: a comparison of inferential models across the NitroEurope network, Atmos. Chem. Phys., 11, 2703-2728, doi:10.5194/acp-11-2703-2011, 2011

Fontijn, A., Sabadell, A. J., and Ronco, R. J.: Homogeneous chemiluminescent measurement of nitric oxide with ozone, Anal. Chem., 42, 575-579, 1970.

Galloway, J. N., Aber, J. D., Erisman, J. W., Seitzinger, S. P., Howarth, R. W., Cowling, E. B., and Cosby, B. J.: The Nitrogen
Cascade, BioScience, 53, 341-356, 2003.

Hegglin, M. I., Brunner, D., Peter, T., Hoor, P., Fischer, H., Staehelin, J., Krebsbach, M., Schiller, C., Parchatka, U., and Weers, U.: Measurements of $\mathrm{NO}, \mathrm{NO}_{\mathrm{y}}, \mathrm{N}_{2} \mathrm{O}$, and $\mathrm{O}_{3}$ during SPURT: implications for transport and chemistry in the lowermost stratosphere, Atmos. Chem. Phys., 6, 1331-1350, doi:10.5194/acp-61331-2006, 2006.

Hesterberg, R., Blatter, A., Fahrni, M., Rosset, M., Neftel, A., Eugster, W., and Wanner, H.: Deposition of nitrogen-containing compounds to an extensively managed grassland in central Switzerland, Environ. Poll., 91, 21-34, 1996.

Horii, C. V., Munger, J. W., and Wofsy, S. C.: Fluxes of nitrogen oxides over a temperate deciduous forest, J. Geophys. Res., 109, D08305, doi:10.1029/2003JD004326, 2004.

Horii, C. V., Munger, J. W., Wofsy, S. C., Zahniser, M., Nelson, D., and McManus, J. B.: Atmospheric reactive nitrogen concentration and flux budgets at a Northwestern US forest, Agr. Forest Meteorol., 136, 159-174, 2006.

Kita, K., Morino, Y., Kondo, Y., Komazaki, Y., Takegawa, N., Miyazaki, Y., Hirokawa, J., Tanaka, S., Thompson, T. L., Gao, R. S., and Fahey, D. W.: A chemical ionization mass spectrometer for ground-based measurements of nitric acid, J. Atmos. Ocean. Tech., 23, 1104-1113, 2006.

Kliner, D. A. V., Daube, B. C., Burley, J. D., and Wofsy, S. C.: Laboratory investigations of the catalytic reduction technique for measurement of atmospheric $\mathrm{NO}_{\mathrm{y}}$, J. Geophys. Res., 102, 1075910776, 1997.

Kroon, P. S., Schuitmaker, A., Jonker, H. J. J., Tummers, M. J., Hensen, A., and Bosveld, F. C.: An evaluation by laser Doppler anemometry of the correction algorithm based on Kaimal cospectra for high frequency losses of EC flux measurements of $\mathrm{CH}_{4}$ and $\mathrm{N}_{2} \mathrm{O}$, Agr. Forest Meteorol., 150, 794-805, 2010.

McCalley, C. K. and Sparks, J. P.: Abiotic Gas Formation Drives Nitrogen Loss from a Desert Ecosystem, Science, 326, 837-840, 2009.

Meixner, F. X.: Surface exchange of odd nitrogen oxides, Nova Act. LC, 70, 299-348, 1994.

Mozurkewich, M.: The dissociation constant of ammonium nitrate and its dependence on temperature, relative humidity and particle size, Atmospheric Environment A-Gen., 27, 261-270, 1993.

Munger, J. W., Wofsy, S. C., Bakwin, P. S., Fan, S.-M., Goulden, M. L., Daube, B. C., and Goldstein, A. H.: Atmospheric deposition of reactive nitrogen oxides and ozone in a temperate deciduous forest and a subarctic woodland, 1. Measurements and mechanisms, J. Geophys. Res., 101, 12639-12657, 1996.

Munger, J. W., Fan, S.-M. Bakwin, P. S., Goulden, M. L., Goldstein, A. H., Colman, A. S., and Wofsy, S. C.: Regional budgets for nitrogen oxides from continental sources: Variations of rates for oxidation and deposition with season and distance from source regions, J. Geophys. Res., 103, 8355-8368, 1998.

Neftel, A., Ammann, C., Fischer, C., Spirig, C., Conen, F., Emmenegger, L., Tuzson, B., and Wahlen, S.: $\mathrm{N}_{2} \mathrm{O}$ exchange over managed grassland: Application of a quantum cascade laser spectrometer for micrometeorological flux measurements, Agr. Forest Meteorol., 150, 775-785, 2010.

Nemitz, E., Dorsey, J. R., Flynn, M. J., Gallagher, M. W., Hensen, A., Erisman, J.-W., Owen, S. M., Dämmgen, U., and Sutton, M. A.: Aerosol fluxes and particle growth above managed grassland, Biogeosciences, 6, 1627-1645, doi:10.5194/bg-6-1627- 
2009, 2009.

Pollack, I. B., Lerner, B. M., and Ryerson, T. B.: Evaluation of ultraviolet light-emitting diodes for detection of atmospheric $\mathrm{NO}_{2}$ by photolysis - chemiluminescence, J. Atmos. Chem., 65, 111-125, 2010.

Rinne, J., Pihlatie, M., Lohila, A., Thum, T., Aurela, M., Tuovinen, J., Laurila, T., and Vesala, T.: Nitrous oxide emissions from a municipal landfill, Environ. Sci. Technol., 39, 7790-7793, 2005.

Rosen, R. S., Wood, E. C., Wooldridge, P. J., Thornton, J. A., Day, D. A., Kuster, W., Williams, E. J., Jobson, B. T., and Cohen, R. C.: Observations of total alkyl nitrates during Texas Air Quality Study 2000: Implications for $\mathrm{O}_{3}$ and alkyl nitrate photochemistry, J. Geophys. Res., 109, D07303, doi:10.1029/2003JD004227, 2004.

Rummel, U., Ammann, C., Gut, A., Meixner, F. X., and Andreae, M. O.: Eddy covariance measurements of nitric oxide flux within an Amazonian rain forest, J. Geophys. Res., 107, 8050, doi:10.1029/2001JD000520, 2002.

Seinfeld, J. H. and Pandis, S. N.: Atmospheric Chemistry and Physics - From Air Pollution to Climate Change, Second Edition, John Wiley and Sons Inc., 1232 pp., 2006.

Shaw, W. J., Spicer, C. W., and Kenny, D. V.: Eddy correlation fluxes of trace gases using a tandem mass spectrometer, Atmos. Environ., 32, 2887-2898, 1998.

Sigsby, J. E., Black, F. M., Bellar, T. A., and Klosterman, D. L.: Chemiluminescent method for analysis of nitrogen containing compounds in mobile source emissions $\left(\mathrm{NO}, \mathrm{NO}_{2}\right.$, and $\left.\mathrm{NH}_{3}\right)$, Environ. Sci. Technol., 7, 51-54, 1973.

Sintermann, J., Spirig, C., Jordan, A., Kuhn, U., Ammann, C., and Neftel, A.: Eddy covariance flux measurements of ammonia by high temperature chemical ionisation mass spectrometry, Atmos. Meas. Tech., 4, 599-616, doi:10.5194/amt-4-599-2011, 2011.

Simpson, D., Butterbach-Bahl, K., Fagerli, H., Kesik, M., Skiba, U., and Tang, S.: Deposition and Emissions of Reactive Nitrogen over European Forests: A Modelling Study, Atmos. Environ., 40, 5712-5726, 2006.

Spirig, C., Flechard, C. R., Ammann, C., and Neftel, A.: The annual ammonia budget of fertilised cut grassland - Part 1: Micrometeorological flux measurements and emissions after slurry application, Biogeosciences, 7, 521-536, doi:10.5194/bg-7-521-2010, 2010

Stelson, A. W., Friedlander, S. K., and Seinfeld, J. H.: Note on the equilibrium relationship between ammonia and nitric-acid and particulate ammonium-nitrate, Atmos. Environ., 13, 369-371, 1979.

Sutton, M. A., Nemitz, E., Erisman, J. W., Beier, C., ButterbachBahl, K., Cellier, P., de Vries, W., Cotrufo, F., Skiba, U., Di Marco, C., Jones, S., Laville, P., Soussana, J. F., Loubet, B., Twigg, M., Famulari, D., Whitehead, J., Gallagher, M. W., Neftel, A., Flechard, C. R., Herrmann, B., Calanca, P. L., Schjoerring, J. K., Dämmgen, U., Horvath, L., Tang, Y. S., Emmett, B. A., Tietema, A., Peñuelas, J., Kesik, M., Brüggemann, N., Pilegaard, K., Vesala, T., Campbell, C. L., Olesen, J. E., Dragosits, U., Theobald, M. R., Levy, P., Mobbs, D. C., Milne, R., Viovy, N., Vuichard, N., Smith, J. U., Smith, P., Bergamaschi, P., Fowler, D., and Reis, S.: Challenges in quantifying biosphereatmosphere exchange of nitrogen species, Environ. Pollut., 150, 125-139, 2007.
Sutton, M. A., Billen, G., Bleeker, A., Erisman, J. W., Grennfelt, P., van Grinsven, H., Grizzetti, B., Howard, C. M., and Leip, A.: Technical Summary of The European Nitrogen Assessment, edited by: Sutton, M. A., Howard, C. M., Erisman, J. W., Billen, G., Bleeker, A., Grennfelt, P., van Grinsven, H., and Grizzetti, B., Cambridge University Press, 2011.

Thomas, R. M., Trebs, I., Otjes, R., Jongejan, P. A. C., Ten Brink, H., Phillips, G., Kortner, M., Meixner, F. X., and Nemitz, E.: An automated analyzer to measure surface-atmosphere exchange fluxes of water soluble inorganic aerosol compounds and reactive trace gases, Environ. Sci. Technol., 43, 1412-1418, 2009.

Thornton, J. A., Wooldridge, P. J., Cohen, R. C., Williams, E. J., Hereid, D. P., Fehsenfeld, F. C., Stutz, J., and Alicke, B.: Comparisons of in situ and long path measurements of NO2 in urban plumes, J. Geophys. Res., 108, 4496, doi:10.1029/2003JD003559, 2003.

Tuzson, B., Hiller, R. V., Zeyer, K., Eugster, W., Neftel, A., Ammann, C., and Emmenegger, L.: Field intercomparison of two optical analyzers for $\mathrm{CH}_{4}$ eddy covariance flux measurements, Atmos. Meas. Tech., 3, 1519-1531, doi:10.5194/amt-3-1519-2010, 2010.

Twigg, M. M., House, E., Thomas, R., Whitehead, J., Phillips, G. J., Famulari, D., Fowler, D., Gallagher, M. W., Cape, J. N., Sutton, M. A., Nemitz, E.: Surface/atmosphere exchange and chemical interactions of reactive nitrogen compounds above a manured grassland, Agr. Forest Meteorol., 151, 1488-1503, 2011.

von Bobrutzki, K., Braban, C. F., Famulari, D., Jones, S. K., Blackall, T., Smith, T. E. L., Blom, M., Coe, H., Gallagher, M., Ghalaieny, M., McGillen, M. R., Percival, C. J., Whitehead, J. D., Ellis, R., Murphy, J., Mohacsi, A., Pogany, A., Junninen, H., Rantanen, S., Sutton, M. A., and Nemitz, E.: Field inter-comparison of eleven atmospheric ammonia measurement techniques, Atmos. Meas. Tech., 3, 91-112, doi:10.5194/amt-3-91-2010, 2010.

Wexler, A. S. and Seinfeld, J. H.: Second-generation inorganic aerosol model, Atmos. Environ., 25, 2731-2748, 1991.

Winer, A. M., Peters, J. W., Smith, J. P., and Pitts, J. N.: Response of commercial chemiluminescent $\mathrm{NO}-\mathrm{NO}_{2}$ analyzers to other nitrogen-containing compounds, Environ. Sci. Technol., 8, 1118-1121, 1974.

Wolff, V., Trebs, I., Ammann, C., and Meixner, F. X.: Aerodynamic gradient measurements of the $\mathrm{NH}_{3}-\mathrm{HNO}_{3}-\mathrm{NH}_{4} \mathrm{NO}_{3}$ triad using a wet chemical instrument: an analysis of precision requirements and flux errors, Atmos. Meas. Tech., 3, 187-208, doi:10.5194/amt-3-187-2010, 2010a.

Wolff, V., Trebs, I., Foken, T., and Meixner, F. X.: Exchange of reactive nitrogen compounds: concentrations and fluxes of total ammonium and total nitrate above a spruce canopy, Biogeosciences, 7, 1729-1744, doi:10.5194/bg-7-1729-2010, 2010 b.

Wyers, G. P., Otjes, R. P., and Slanina, J.: A continuous-flow denuder for the measurement of ambient concentrations and surface-exchange fluxes of ammonia, Atmos. Environ., 27, 2085-2090, 1993.

Zimmerling, R., Dämmgen, U., Grünhage, L., Haenel, H.-D., Küsters, A., Max, W., and Jäger, H.-J.: The Classifying Ratiometric Method for the Continuous Determination of Atmospheric Flux Densities of Reactive N- and S-Species with Denuder Filter Systems, J. Appl. Bot., 71, 38-49, 1997. 